\title{
Effect of stocking on juvenile wood stiffness for three Eucalyptus species
}

\author{
Edward Warren · R. Geoff B. Smith · Luis Alejandro Apiolaza • \\ John C. F. Walker
}

Received: 19 August 2008/Accepted: 13 November 2008/Published online: 25 November 2008

(C) Springer Science+Business Media B.V. 2008

\begin{abstract}
The effects of stocking on wood stiffness (MoE) for three Eucalyptus species are quantified using a 6-year-old trial established in New South Wales, Australia. An acoustic time-of-flight tool measured the velocity between two probes in the outerwood, from which the stiffness was estimated. Four stocking levels (714, 1,250, 1,667 and 3,333 sph) were examined. Stiffness varied significantly between all species, with E. cloeziana showing the highest stiffness (14.2-15.7 GPa), followed by E. pilularis (12.2-13.5 GPa) and E. dunnii (10.7-12.6 GPa). There was a stiffness increase (around 11\%) between 714 and 1,250 stems/ha for all species but thereafter differences between stockings were not always significant. Trees were also assessed for basic density, $d b h$, total height, crown area, green crown height and stem slenderness (height/dbh). Only stem slenderness had a significant association $(0.41 \pm 0.17)$ with stiffness. These findings suggest that, where stiffness is a priority, forest managers could reduce establishment costs with low stockings (around 1,250 stems/ha).
\end{abstract}

Keywords Wood stiffness $\cdot$ Stocking $\cdot$ Eucalyptus $\cdot$ Silviculture

E. Warren · L. A. Apiolaza $(\bowtie) \cdot$ J. C. F. Walker

School of Forestry, University of Canterbury, Private Bag 4800,

Christchurch, New Zealand

e-mail: Luis.Apiolaza@canterbury.ac.nz

Present Address:

E. Warren

Pöyry Forest Industry Ltd., Level 5 HSBC Building,

1 Queen St., Auckland, New Zealand

R. G. B. Smith

Land Management and Technical Services Division, Forests NSW, Coffs Harbour, NSW 2450, Australia 


\section{Introduction}

Eucalyptus is a fast growing diffuse-porous hardwood genus used in plantation forestry around the world. Intrinsic wood properties vary greatly with species, stocking levels and locations in which they are grown. This is further compounded by large variations both between and within trees that occur within a single stand.

Effects of initial stocking and tree position in the stand on wood stiffness have been reported in another genus. Lasserre et al. (2005) observed that the stiffness of 11 year-old radiata pine was noticeably less in stands with lower stockings, while Bascuñán (2004) noted that trees of all ages near forest margins were less stiff than trees growing in the interior. Trees in open-grown stands or near forest margins are exposed to wind and because of this they need to absorb the dynamic energy of wind gusts, while also maintaining their dominance.

Maximum energy absorption (damping) requires a microfibril angle of around 25-30 (Reiterer et al. 2001; Gordon and Jeronimidis 1980), while to retain apical dominance softwoods need to form compression wood with a microfibril angle of around 40-50 . In the case of radiata pine, the importance of the latter is reflected in the high proportion of compression wood in corewood/juvenile wood-typically around 20\% (Burdon et al. 2004). On the other hand, hardwoods form tension wood with a microfibril angle of around $0-5^{\circ}$. The intrinsic quality of the corewood/juvenile wood of hardwoods is noticeably superior to that of softwoods (Chauhan and Walker 2006), because the microfibril angles in young hardwoods lie in the range $10-30^{\circ}$, whereas the microfibril angles in young softwoods lie in the range $25-50^{\circ}$. The higher the microfibril angle the lower is the wood stiffness. Thus, hardwoods-eucalypts in particular-are strong candidates for shortrotation plantations with high wood stiffness.

Wood stiffness, expressed as Young's modulus of elasticity (MoE), is generally more critical than strength in engineered structures. Furthermore, low stiffness wood risks warp, i.e. bow and crook (Xu and Walker 2004). Stiffness of the outerwood of standing trees can be estimated non-destructively with a time of flight tool (ToF), which measures the time taken for an introduced stress wave to travel a known distance from one point up the stem to another. The velocity of the stress wave is directly related to the static MoE (Grabianowski 2003).

Portable acoustic tools are useful in that they offer a fast and accurate way of estimating stiffness in standing trees (Lasserre et al. 2005). Acoustic tools also provide opportunities to mass screen trees for stiffness at a very young age (Lindström et al. 2002). These tools can segregate logs according to intrinsic wood quality, and remove outliers from the wood flow during post-harvest sorting and grading (Dickson et al. 2003).

In this paper we characterise a 6 year-old trial of Eucalyptus cloeziana, E. pilularis and E. dunnii with sample plots at various stockings levels. We aim to relate the observed variability of wood stiffness to species, stocking and tree level variables like basic density, tree height, diameter at breast height $(d b h)$, green crown height and stem slenderness.

\section{Materials and methods}

\section{Site description}

The study was undertaken in a Forests New South Wales (NSW) silvicultural regime trial at Southgate, adjacent to the Orara River in the Coffs Harbour district of New South Wales, 
Australia. The climate is characterised as humid subtropical, with an average annual rainfall of approximately $1,500 \mathrm{~mm}$ and $50 \%$ of the total annual rain falling during the summer. The average temperature at Coffs Harbour varies from a minimum average of $6.8^{\circ} \mathrm{C}$ in winter to $18.6^{\circ} \mathrm{C}$ in summer. ${ }^{1}$ Soils of the slopes in the east paddock were generally deep $(>150 \mathrm{~cm})$ moderately well drained soils with very dark brown clay loam topsoils grading into well structured strong brown clay subsoils over mottled poorly structured clays from around $100 \mathrm{~cm}$. They are classified as Brown Dermosols (Isbell 1996). Chemical analysis of the surface horizon of nearby similar soils indicated they were very strongly acidic with high levels of total $\mathrm{N}$ and organic $\mathrm{C}$ and moderate total $\mathrm{P}$. Soils in the west paddock are deep alluvial soils on the Orara River flat. Eucalyptus dunnii was planted on the river flats in the west paddock, E. cloeziana and E. pilularis on the slopes in the east paddock. E. cloeziana and E. pilularis were planted in January 2000 while E. dunnii was planted in March (NSW State Forests Establishment Report 2001). The assessments for this study were recorded in July 2006.

Experimental design and treatments

All trees were unimproved stock planted at four initial stockings: $714(4 \times 3.5 \mathrm{~m}), 1,250$ $(4 \times 2 \mathrm{~m}), 1,667(4 \times 1.5 \mathrm{~m})$ and $3,333(4 \times 0.75 \mathrm{~m})$ stems/ha. The plots were $30 \mathrm{~m}$ wide and eight rows deep, to allow for six internal sample rows with a buffer row on all four sides of each plot. There were three replicate plots per species at each of the four stocking levels for a total of 36 plots. Tree form was taken into consideration while selecting 20 trees per plot covering the range of stem diameter, for a total of 240 trees per species.

\section{Measurements and calculations}

The measured growth variables were diameter at breast height $(d b h$, measured at $1.3 \mathrm{~m}$ to the nearest millimetre), tree height (measured with a vertex to the nearest $10 \mathrm{~cm}$ ), height to green crown (measured with a height pole to the nearest $10 \mathrm{~cm}$ ) and crown width in both axes (major and minor to the nearest $10 \mathrm{~cm}$ ). Stem slenderness was approximated by dividing tree height by $d b h$.

Stiffness was measured with a ToF tool (TreeTap), lightly tapping two spiked metal receiver probes into the outerwood of the tree at 0.6 and $1.9 \mathrm{~m}$ from the ground. Then a third probe was driven into the outerwood of the tree $20 \mathrm{~cm}$ below the lowest of the two receiver transducers. Lightly tapping the third probe with a hammer generated an acoustic stress wave along the tree. The acoustic velocity of the wave was calculated dividing the distance the acoustic signal had to travel between the two receiving probes by the lapsed time and expressed in $\mathrm{km} / \mathrm{s}$ (Grabianowski 2003; Lasserre et al. 2004). The start probe was tapped eight times per side of each tree to ensure the reliability and accuracy of the resulting transit time, because time generally varies slightly between taps. The estimated acoustic velocity was the averaged value from measurements taken on opposite sides of each tree. The acoustic velocity was used to estimate the outerwood stiffness of each tree using the following equation:

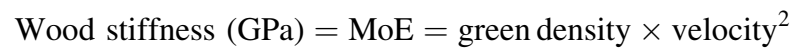

\footnotetext{
1 Australian Government Bureau of Meteorology website, http://www.bom.gov.au/weather/nsw/coffs_harbour/ climate_and_history.shtml.
} 
where the value for the green density of the outerwood was $1,100 \mathrm{~kg} / \mathrm{m}^{3}$ and velocity was acoustic velocity along the grain, measured by TreeTap.

Finally, a single $5 \mathrm{~mm}$ diameter outerwood increment core at breast height was extracted and stored in a drinking straw over ice. In the laboratory, the green outerwood increment cores were resaturated using five vacuum-pressure cycles over several hours while immersed, and then keeping immersed for a further three days, before weighing them green and oven dry (Smith 1954). The basic density from the single increment core was used to calculate a "normalised" tree outerwood stiffness (cell wall stiffness), effectively determining the stiffness of green cell wall material. To calculate green cell wall stiffness the measured stiffness was adjusted to take account of the proportion of the cross-section that was accounted for by the swollen wall tissue, by dividing acoustic stiffness by the basic density multiplied by $0.933 \times 10^{-3}$.

Data analysis

The effects of stocking levels, species and their interaction on the assessed variables were examined using analysis of variance of the plot means with the following model:

$$
y_{i j k}=\mu+s_{i}+n_{j}+s n_{i j}+e_{i j k}
$$

where $y_{i j k}$ is the response variable, $\mu$ is the overall mean, $s_{i}$ the effect of the $\mathrm{i}^{\text {th }}$ species, $n_{j}$ the effect of the $\mathrm{j}^{\text {th }}$ stocking level, $s n_{i j}$ the interaction between species and stocking and $e_{i j k}$ random residuals with variance $\sigma_{e}^{2}$.

A bivariate version of this model - to calculate residual correlation between traits adjusted by species, stocking and their interaction-was created by 'stacking up' the vectors for two traits. The residuals are then defined as $\mathbf{R}_{0} \otimes \mathbf{I}$, where $\mathbf{R}_{0}$ is the individual residual covariance matrix, $\otimes$ is the Kronecker product and $\mathbf{I}$ is an identity matrix of order number of plots (36).

$$
\mathbf{R}_{0}=\left[\begin{array}{cc}
\sigma_{e 1}^{2} & \sigma_{e 12} \\
\sigma_{e 12} & \sigma_{e 2}^{2}
\end{array}\right]
$$

where $\sigma_{e 1}^{2}$ and $\sigma_{e 2}^{2}$ are random residuals for variable 1 and 2 , respectively, and $\sigma_{e 12}$ is the residual covariance between both variables. The correlation $(r)$ is calculated as:

$$
r=\frac{\sigma_{e 12}}{\sqrt{\sigma_{e 1}^{2} \sigma_{e 2}^{2}}}
$$

All significance tests were performed at the $95 \%$ level $(P<0.05)$.

\section{Results and discussion}

Wood quality traits

There were significant differences for outerwood stiffness (MoE) between all species $(P<0.001)$, with $E$. cloeziana showing the highest stiffness $(14.2-15.7 \mathrm{GPa})$, followed by E. pilularis (12.2-13.5 GPa) and E. dunnii (10.7-12.6 GPa).

There was a marked increase between 714 and 1,250 stems/ha for all three species but thereafter differences between stockings were less obvious, which may relate to a lower need to absorb the dynamic energy of wind gusts. Table 1 shows least square means and 
Table 1 Least square means (and standard errors) for assessed variables under different species and stockings

\begin{tabular}{|c|c|c|c|c|c|c|c|c|c|c|}
\hline \multirow{3}{*}{$\begin{array}{l}\text { Variable } \\
\text { Wood stiffness (GPa) }\end{array}$} & \multirow{3}{*}{$\begin{array}{l}\text { Stocking (stems/ } \\
\text { ha) } \\
714\end{array}$} & \multicolumn{9}{|c|}{ Species } \\
\hline & & \multicolumn{3}{|c|}{ E. cloeziana } & \multicolumn{2}{|c|}{ E. dunnii } & \multicolumn{4}{|c|}{ E. pilularis } \\
\hline & & 14.2 & $(0.4)$ & A & 10.7 & $(0.4)$ & A & 12.2 & $(0.4)$ & A \\
\hline & 1,250 & 15.7 & $(0.4)$ & B & 11.9 & $(0.4)$ & B & 13.5 & $(0.4)$ & B \\
\hline & 1,667 & 15.6 & $(0.4)$ & B & 12.2 & $(0.4)$ & B & 13.2 & $(0.4)$ & $\mathrm{AB}$ \\
\hline & 3,333 & 15.0 & $(0.4)$ & A & 12.6 & $(0.4)$ & B & 13.4 & $(0.4)$ & B \\
\hline \multirow{4}{*}{$\begin{array}{l}\text { Cell wall stiffness } \\
(\mathrm{GPa})\end{array}$} & 714 & 28.2 & $(0.9)$ & A & 27.3 & $(0.9)$ & A & 28.6 & $(0.9)$ & A \\
\hline & 1,250 & 31.3 & $(0.9)$ & B & 29.9 & $(0.9)$ & B & 31.7 & $(0.9)$ & B \\
\hline & 1,667 & 32.1 & $(0.9)$ & B & 30.1 & $(0.9)$ & B & 32.7 & $(0.9)$ & B \\
\hline & 3,333 & 30.5 & $(0.9)$ & $\mathrm{AB}$ & 31.4 & $(0.9)$ & B & 32.4 & $(0.9)$ & B \\
\hline \multirow[t]{4}{*}{ Basic density $\left(\mathrm{kg} / \mathrm{m}^{3}\right)$} & 714 & 540.7 & (5.8) & A & 419.3 & $(5.8)$ & A & 458.0 & (5.8) & A \\
\hline & 1,250 & 543.2 & $(5.8)$ & A & 425.2 & (5.8) & A & 459.3 & $(5.8)$ & A \\
\hline & 1,667 & 521.7 & $(5.8)$ & $\mathrm{B}$ & 434.7 & $(5.8)$ & $\mathrm{A}$ & 433.4 & $(5.8)$ & $\mathrm{B}$ \\
\hline & 3,333 & 528.1 & (5.8) & $\mathrm{AB}$ & 431.3 & $(5.8)$ & A & 443.3 & $(5.8)$ & $\mathrm{AB}$ \\
\hline \multirow[t]{4}{*}{$d b h(\mathrm{~cm})$} & 714 & 16.7 & $(0.4)$ & A & 16.2 & $(0.4)$ & A & 17.1 & $(0.4)$ & A \\
\hline & 1,250 & 18.0 & $(0.4)$ & A & 14.9 & $(0.4)$ & B & 15.5 & $(0.4)$ & B \\
\hline & 1,667 & 17.2 & $(0.4)$ & A & 14.6 & $(0.4)$ & $\mathrm{BC}$ & 16.3 & $(0.4)$ & A \\
\hline & 3,333 & 14.4 & $(0.4)$ & B & 13.3 & $(0.4)$ & C & 14.3 & $(0.4)$ & B \\
\hline \multirow[t]{4}{*}{ Height (m) } & 714 & 14.9 & $(0.4)$ & A & 14.5 & $(0.4)$ & A & 15.2 & $(0.4)$ & A \\
\hline & 1,250 & 17.6 & $(0.4)$ & B & 15.2 & $(0.4)$ & A & 15.5 & $(0.4)$ & $\mathrm{AB}$ \\
\hline & 1,667 & 18.1 & $(0.4)$ & $\mathrm{B}$ & 15.4 & $(0.4)$ & A & 16.6 & $(0.4)$ & $\mathrm{B}$ \\
\hline & 3,333 & 16.3 & $(0.4)$ & C & 14.9 & $(0.4)$ & A & 15.0 & (0.4) & A \\
\hline \multirow[t]{4}{*}{ Crown area $\left(\mathrm{m}^{2}\right)$} & 714 & 101.5 & (4.7) & A & 66.3 & (4.7) & A & 61.6 & $(4.7)$ & A \\
\hline & 1,250 & 87.4 & (4.7) & B & 37.1 & (4.7) & B & 36.4 & $(4.7)$ & B \\
\hline & 1,667 & 62.3 & (4.7) & $\mathrm{C}$ & 32.6 & (4.7) & B & 37.3 & $(4.7)$ & B \\
\hline & 3,333 & 40.4 & (4.7) & $\mathrm{D}$ & 25.1 & (4.7) & B & 28.3 & (4.7) & $\mathrm{B}$ \\
\hline \multirow{4}{*}{$\begin{array}{l}\text { Green crown height } \\
\text { (m) }\end{array}$} & 714 & 2.0 & $(0.4)$ & A & 2.4 & $(0.4)$ & A & 5.0 & $(0.4)$ & A \\
\hline & 1,250 & 4.5 & $(0.4)$ & B & 3.7 & $(0.4)$ & B & 6.2 & $(0.4)$ & B \\
\hline & 1,667 & 5.9 & $(0.4)$ & $\mathrm{C}$ & 4.4 & $(0.4)$ & $\mathrm{BC}$ & 7.5 & $(0.4)$ & $\mathrm{C}$ \\
\hline & 3,333 & 5.2 & $(0.4)$ & $\mathrm{BC}$ & 5.0 & $(0.4)$ & $\mathrm{C}$ & 7.0 & $(0.4)$ & $\mathrm{BC}$ \\
\hline \multirow[t]{4}{*}{ Slenderness $(\mathrm{m} / \mathrm{cm})$} & 714 & 0.91 & $(0.02)$ & $\mathrm{A}$ & 0.90 & $(0.02)$ & A & 0.90 & $(0.02)$ & A \\
\hline & 1,250 & 1.00 & $(0.02)$ & B & 1.03 & $(0.02)$ & B & 1.01 & $(0.02)$ & B \\
\hline & 1,667 & 1.06 & $(0.02)$ & $\mathrm{C}$ & 1.06 & $(0.02)$ & $\mathrm{BC}$ & 1.03 & $(0.02)$ & B \\
\hline & 3,333 & 1.14 & $(0.02)$ & $\mathrm{D}$ & 1.12 & $(0.02)$ & C & 1.05 & $(0.02)$ & B \\
\hline
\end{tabular}

Within-species multiple comparisons use the same letter to denote not statistically significant differences

their standard errors for all variables, together with multiple comparisons within species (at the $P=0.05$ level). Wood stiffness for the lowest stocking (714 stems/ha) was significantly different from that of 1,250 stems/ha for all species. This difference is also significant for 714 versus 1,667 for E. cloeziana, 714 versus 1,667 and 714 versus 3,333 for E. dunnii, and 714 versus 3,333 for E. pilularis. However, wood stiffness does not necessarily continue increasing over 1,250 stems/ha, as shown for the other comparisons which are not significant (Table 1; Fig. 1). 

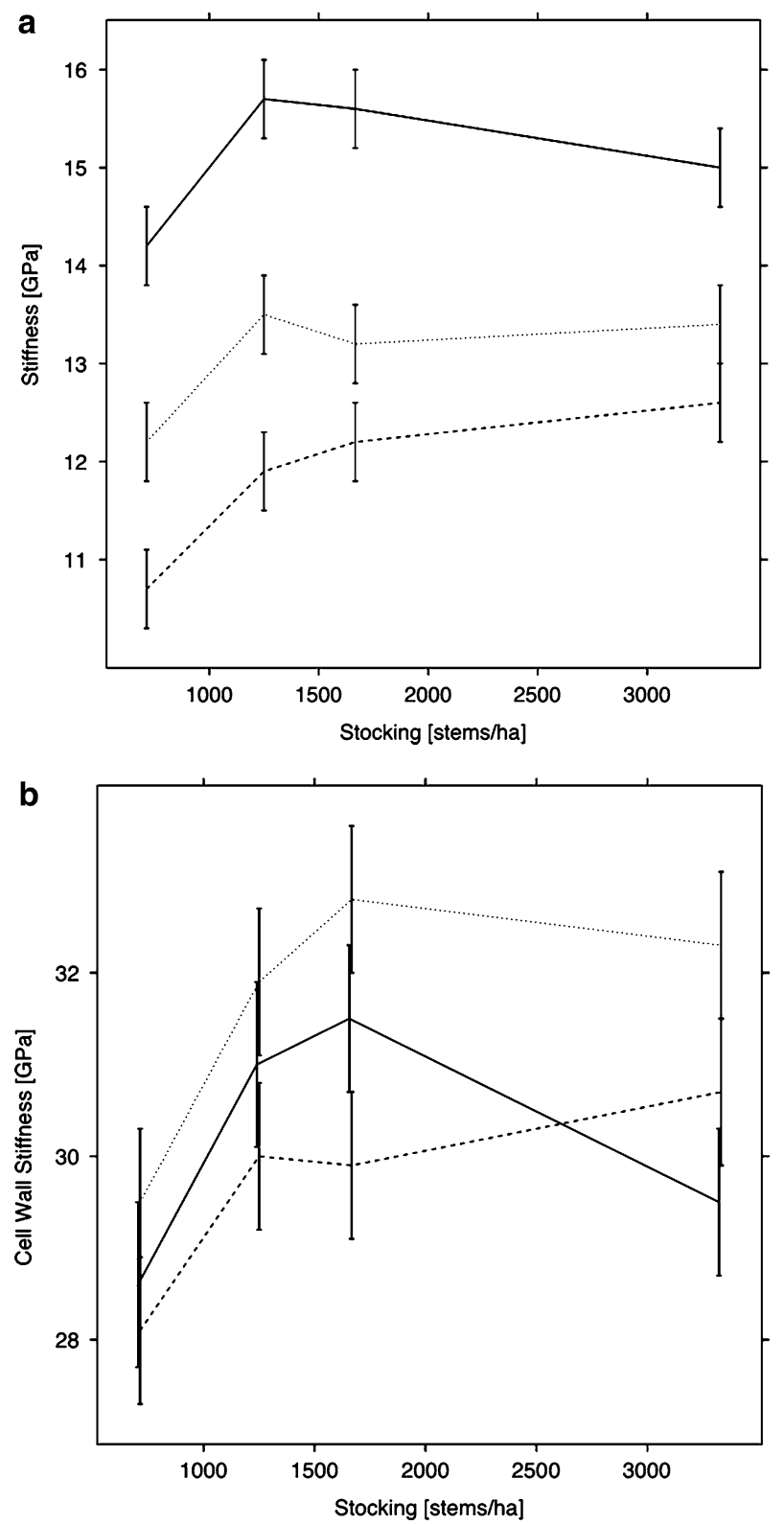

Fig. 1 Outerwood stiffness (a) and cell wall stiffness (b) for E. cloeziana (solid line), E. dunnii (dashed line) and E. pilularis (dotted line) across four stocking levels. When considering basic density and wood stiffness together to calculate cell wall stiffness, the differences between species are reduced. In addition, the relative rankings change

The increase of stiffness with stocking agrees with findings for Pinus radiata (Grabianowski et al. 2004). However, the pine trees were much older (age 27) and stockings were much lower, ranging from 100 to 625 stems/ha. It has been hypothesised that at the lower stockings the low level of crown-competition and large openings between 
trees allow increased wind sway that in turn could result in decreased wood stiffness. In contrast, Waghorn et al. (2007) reported that MoE continued increasing from 275 to 2,551 stems/ha. Nevertheless, little is known about the affect of wind in regulating tree stiffness in these particular Eucalyptus species.

When lumen space was taken into account for calculating an average cell wall stiffness, E. pilularis had the highest value (28.6-32.7 GPa), followed by E. cloeziana (28.2-32.1 $\mathrm{GPa}$ ) and E. dunnii (27.3-31.4 GPa). The differences between E. pilularis and E. dunnii were statistically significant. The change in ranking between the species (Fig. 1a vs. b) was due to differences in basic densities between them.

Concerning within species differences for cell wall stiffness, E. cloeziana showed significant differences between 714 and 1,250 stems/ha, and 714 and 1,667 stems/ha. E. pilularis and $E$. dunnii presented differences between 714 stems/ha and all other stockings (Table 1).

There were significant differences for basic density between species, where E. cloeziana was the densest $\left(533.4 \mathrm{~kg} / \mathrm{m}^{3}\right)$, followed by E. pilularis $\left(448.5 \mathrm{~kg} / \mathrm{m}^{3}\right)$ and E. dunnii $\left(427.6 \mathrm{~kg} / \mathrm{m}^{3}\right)$. Within-species stocking differences for basic density were less pronounced than for wood stiffness. In the case of $E$. dunnii there were no significant differences between stockings, while for E. cloeziana and E. pilularis only the differences between 714 and 1,667 stems/ha, and between 1,250 and 1,667 stems/ha were significant. Basic density was the only wood quality trait that showed significant interactions between species and stocking, mostly due to density changes from 714 to 1,250 stems/ha.

\section{Growth traits}

There were significant differences for stem diameter for species, stocking and their interaction, with the poorest growth for E. dunnii $(13.3-16.2 \mathrm{~cm})$ under all stockings. The relative rankings of E. cloeziana $(14.4-18.0 \mathrm{~cm})$ and E. pilularis $(14.3-17.1 \mathrm{~cm})$ did change with stocking; there were no significant differences between these two species at most stockings, but E. cloeziana was superior at 1,250 stems/ha. There was only one significant difference for stocking in E. cloeziana, where 3,333 stems/ha produced much smaller trees. In the case of E. dunnii there were significant differences between 714 stems/ ha and (1) the treatments with 1,250 and 1,667 stems/ha, and (2) 3,333 stems/ha. Finally, E. pilularis showed differences between treatments with 714 and 1,667 stems/ha, and treatments with 1,250 and 3,333 stems/ha.

The differences for total tree height were significant for both species and stocking, but not for their interaction. E. cloeziana is significantly taller $(14.9-18.1 \mathrm{~m})$ than both E. dunnii (14.5-15.4 m) and E. pilularis (15.0-16.6 m), but there are no significant differences between the last two. E. dunnii did not show significant differences in height for stocking. However, E. cloeziana and E. pilularis had significant differences between 714 stems/ha and both 1,250 and 1,667 stems/ha. E. cloeziana also had significant differences between 714 and 3,333 stems/ha, and between 1,667 and 3,333 stems/ha.

There are significant differences for crown area between E. cloeziana and the other two species. There is a minor change of ranking between E. dunnii and E. pilularis, with the former presenting larger crowns at lower stockings (714 and 1,250 stems/ha) and then being overtaken by the latter for higher stockings. For all species there is a significant difference for crown size between 714 stems/ha and all other stockings. In the case of E. dunnii and E. pilularis the difference becomes non-significant for higher stockings; however, for E. cloeziana each stocking is significantly different from the others (Table 1).

The three species show significant differences for green crown height, with the highest value for E. pilularis $(5.0-7.5 \mathrm{~m})$, followed by E. cloeziana $(2.0-5.9 \mathrm{~m})$ and E. dunnii 
(2.4-5.0 m). All species present a significant difference for green crown height between 714 stems/ha and all the other stockings. Further differences tend to be less obvious, although both $E$. cloeziana and E. pilularis also show significant differences between 1,250 and 1,667 stems/ha. E. dunnii also presents a significant difference for green crown height between 1,250 and 3,333 stems/ha (Table 1).

Differences for stem slenderness were significant only for stocking. Slenderness was significantly different between 714 stems/ha and all other stockings for the three species. In the case of E. cloeziana all the differences between stockings were statistically significant.

\section{Relationship between traits}

We considered using growth traits as covariates in the wood quality analyses, but they were confounded with stocking. For example, plots with smaller $d b h$ presented higher stiffness; however, higher stockings also produced smaller diameter trees. This could be seen when plotting individual tree assessments within a given stocking, where the association between wood stiffness and $d b h$ was non-significant. Instead, we estimated the residual correlation between traits using the multivariate version of the model after accounting for the effects of species, stocking and their interaction. Table 2 displays the association of stiffness with basic density, $d b h$, total tree height, crown area, stem slenderness and green crown height. Only the positive correlation between wood stiffness and stem slenderness is statistically significant $(0.41 \pm 0.17)$; that is, for a given stem diameter, taller trees are stiffer.

The lack of significant relationships between $d b h$ and stiffness coincides with findings by Dickson et al. (2003) when measuring 9 and 25 year-old E. dunnii. In contrast Lasserre et al. (2004) explained the significant negative relationship found for Pinus radiata in their study as the result of variation in the latewood percentage between trees of high and low diameter. Lasserre et al. (2004) and Chuang and Wang (2001) found that fast-growing trees with large diameters had a lower percentage of latewood and lower density than trees with a small diameter within the same stand. Latewood tracheids exhibited a higher stiffness than earlywood, meaning that the lower percentage of latewood in larger trees could account for the low stiffness within those trees (Lasserre et al. 2004). Chauhan and Walker (2006) also observed a weak negative linear relationship $\left(R^{2}=0.18\right)$ between stiffness and $d b h$ in an 8 -year-old stand of radiata pine (the larger the tree diameter the less stiff), which was negative but not significant in this study. Perhaps the inverse relationship seen in Eucalyptus relates to different intrinsic latewood and earlywood properties in these hardwood species.

Besides the expected significant associations with height $(0.45 \pm 0.16)$ and $d b h$ $(-0.42 \pm 0.16)$, stem slenderness is also significantly correlated with green crown height $(0.57 \pm 0.14)$ and crown area $(-0.40 \pm 0.17)$. The significant correlation between green crown height and slenderness, with slenderness increasing with green crown height for a given stocking level, is supported by findings in Chapelant (2005). Chapelant (2005) puts

Table 2 Residual correlation (and their standard errors) between variables, removing the effects of species, stocking and their interaction

\begin{tabular}{lllllll}
\hline & $\begin{array}{l}\text { Basic density } \\
\left(\mathrm{kg} / \mathrm{m}^{3}\right)\end{array}$ & $\begin{array}{l}d b h \\
(\mathrm{~cm})\end{array}$ & $\begin{array}{l}\text { Height } \\
(\mathrm{m})\end{array}$ & $\begin{array}{l}\text { Crown area } \\
\left(\mathrm{m}^{2}\right)\end{array}$ & $\begin{array}{l}\text { Slenderness } \\
(\mathrm{mm} / \mathrm{cm})\end{array}$ & $\begin{array}{l}\text { Green crown } \\
\text { height }(\mathrm{m})\end{array}$ \\
\hline Stiffness & & & & & & \\
& $0.16(0.19)$ & $\begin{array}{l}-0.10 \\
(0.20)\end{array}$ & $\begin{array}{l}0.22 \\
(0.19)\end{array}$ & $0.23(0.19)$ & $\mathbf{0 . 4 1}(0.17)$ & $0.02(0.20)$ \\
\hline
\end{tabular}

Only the correlation between wood stiffness and stem slenderness is statistically significant 
this response down to the relationship between tree height and green crown height, and between tree height and radial growth rate. These relationships in turn cause slenderness (calculated from tree height and $d b h$ ) to be related to green crown height. In a similar manner, tree $d b h$ is associated to crown area $(0.49 \pm 0.15$ in our trial), explaining the negative correlation between slenderness and crown area.

Knowledge of the age-related average MoE of species is important for forest owners in deciding which species to plant and at what stocking to produce high-stiffness wood, and so obtain superior economic benefit. However, the results of this study show that the effects of initial stocking below 1,667 stems/ha on stiffness appear to be less than observed for softwoods (Lasserre et al. 2004).

Forest owners will need to weigh the benefits of growth parameters and wood quality traits, as well as their trade-offs (including a potential increase of rotation length), when determining the initial stocking for plantations. Current Eucalyptus species log grading criteria used in New South Wales (New South Wales State Forests 2002) make no mention of intrinsic wood properties such as wood stiffness in defining log grades, a common situation in many countries. Log size, defects and log quality (sweep, bow, crook and twist) are the main considerations in the current grading criteria. This has implications for management and forest growers because there is no specific reward for logs of high stiffness. Any incentive for growing high stiffness timber will need to be based on market demand for high stiffness logs. Ultimately, increased market demand for high stiffness logs will result from increased demand for high stiffness end products such as laminated veneer lumber (LVL). Such studies will be helpful to forest growers to decide on the appropriate silvicultural systems and stockings required to produce high stiffness timber.

\section{Conclusions}

This study examined the effect of stocking on the average MoE of three eucalypts at aged 6. The main finding was that stocking affects tree stiffness although only at lower stocking levels. At this site there appears to be little benefit, with respect to wood stiffness, in planting more than 1,250 stems/ha. Further, the mean stiffness values, even for E. dunnii, are significantly greater than one might anticipate for alternative softwood crops. These findings may have implications for the silvicultural regimes and systems imposed by forest owners. As higher stockings showed no significant increase in tree stiffness over lower stockings, forest owners establishing plantations of these Eucalyptus species for wood quality traits such as stiffness may save resources by establishing plantations at low stocking levels such as 1,250 stems/ha.

Acknowledgments Forests New South Wales provided logistical support for the field work. Lachlan Kirk (School of Forestry, University of Canterbury) provided technical assistance to Eddie Warren in the field. Many thanks to Richard Woollons (School of Forestry, University of Canterbury) for valuable comments on the statistical analyses.

\section{References}

Bascuñán A (2004) The influence of wind on radiata pine tree shape and wood stiffness. Master of science thesis, School of Forestry, University of Canterbury, New Zealand, 199 pp

Burdon RD, Kibblewhite RP, Walker JCF, Megraw RA, Evans R, Cown D (2004) Juvenile versus mature wood: a new concept orthogonal to corewood versus outerwood with special reference to Pinus radiata and $P$. taeda. For Sci 50:399-415 
Chapelant E (2005) New insights for New Zealand's School of Forestry: influence of genotype, weed competition and distance to canopy on wood stiffness. Unpublished report, New Zealand School of Forestry, University of Canterbury, $79 \mathrm{pp}$

Chauhan SS, Walker JCF (2006) Variations in acoustic velocity and density with age, and their interrelationships in Radiata pine. For Ecol Manag 229:388-394

Chuang ST, Wang SY (2001) Evaluation of standing tree quality of Japanese cedar grown with different spacing using stress-wave and ultrasonic-wave methods. J Wood Sci 47:245-253. doi:10.1007/ BF00766709

Dickson RL, Raymond CA, Joe W, Wilkinson CA (2003) Segregation of Eucalyptus dunnii logs using acoustics. For Ecol Manag 179:243-251

Gordon JE, Jeronimidis G (1980) Composites with high work of fracture. Philos Trans R Soc A 294: 545-550. doi:10.1098/rsta.1980.0063

Grabianowski M (2003) Measuring acoustic properties in lumber and trees. Master of Science thesis, School of Forestry, University of Canterbury, New Zealand, $300 \mathrm{pp}$

Grabianowski M, Manley B, Walker JCF (2004) Impact of stocking and exposure on outerwood acoustic properties of Pinus radiata in Eyrewell Forest. N Z J For 49:13-17

Isbell RF (1996) The Australian soil classification. CSIRO, Collingwood, 143 pp

Lasserre JP, Mason EG, Watt M (2004) The influence of initial stocking on corewood stiffness in a clonal experiment of 11-year-old Pinus radiata D.Don. N Z J For 49:18-23

Lasserre JP, Mason EG, Watt M (2005) The effects of genotype and spacing on Pinus radiata (D. Don) corewood stiffness in an 11-year old experiment. For Ecol Manag 205:375-383

Lindström H, Harris P, Nakada R (2002) Methods for measuring stiffness of young trees. Holz Roh Werkst 60:165-217

New South Wales State Forests (2001) State forests establishment report: E. pilularis, E. dunnii, E. cloeziana and $C$. variegata silvicultural regime trial. $11 \mathrm{pp}$

New South Wales State Forests (2002) Log product specifications: North east, mid north coast and hunter regions. NSW State Forests, $31 \mathrm{pp}$

Reiterer A, Lichtenegger H, Fratz P, Stanzl-Tschegg SE (2001) Deformation and energy absorption of wood cell walls with different nanostructure under tensile loading. J Mater Sci 36:4681-4686. doi: 10.1023/A:1017906400924

Smith DM (1954) Maximum moisture content method for determining specific gravity of small wood samples. Report 2014, Forest Products Laboratory, Forest Service, US, Department of Agriculture

Waghorn MJ, Mason EG, Watt MS (2007) Influence of initial stand density and genotype on longitudinal variation in modulus of elasticity for 17-year-old Pinus radiata. For Ecol Manag 252:67-72

$\mathrm{Xu}$ P, Walker JCF (2004) Stiffness gradients in radiata pine trees. Wood Sci Technol 38:1-9. doi: 10.1007/s00226-003-0188-2 